\title{
Container depot location problem in the frame of the Polish part of the New Silk Road
}

\author{
Katarzyna Anna Kuźmicz ${ }^{1 *}$, and Erwin Pesch² \\ ${ }^{1}$ Faculty of Engineering M anagement, Bialystok University of Technology, Bialystok, Poland \\ ${ }^{2}$ Department of $M$ anagement Information Science, University of Siegen, Siegen, Germany
}

\begin{abstract}
The Chinese project One B elt One Road, in Europe often referred to as the New Silk Road, triggers infrastructural investments enabling seamless transportation of goods on the Eurasian route. Since most of these goods are transported in containers, the optimal location of inland container depots, where containers wait for future repositioning after they had been emptied at the importers, is an interesting problem. In this paper conditions determining the optimal location of inland container depots in the Polish part of the NSR are analysed. They include proximity of container transhipment terminals located on the Polish stretch of the NSR, structure of highway network enabling distribution of containers by trucks to other destinations, as well as green aspects mainly referring to avoidance of city congestion caused by trucks transporting containers.
\end{abstract}

Keywords: container depots, empty containers, intermodal transportation, location problem, $\mathrm{N}$ ew Silk RoadPage layout

\section{Introduction}

The Chinese Initiative One Belt One Road (OBOR), also referred to as the New Silk Road (NSR) embraces the development of rail (One Belt) and maritime (21 $1^{\text {st }}$ century Silk Road) transportation corridors linking Europe with China. It can be considered as an important factor triggering changes in Eurasian intermodal transportation. For some kinds of cargo, rail option may become attractive because of the significantly shorter lead time in comparison to maritime transportation. Although the price remains much higher, for those goods for which time of transportation is important rail becomes a good alternative. It could be attractive for example for food producers like meat and dairy products but it has to be taken into consideration that currently these goods are banned from transportation through Russia. Some producers of computers and RTV equipment like HP and Samsung have already shifted their transportation on the Eurasian route to rail taking benefit from the shorter lead time and higher flexibility of inventory supplementation.

Since trade imbalance between China and Europe remains high, an important problem of containers arriving loaded from China and returning empty persists. In the past years, the

* Corresponding author: k.kuzmicz@pb.edu.pl 
trade imbalance between China and the EU amounted to EUR 176 billion [1]. China has been the largest partner for EU imports, and the second-largest partner for EU exports, e.g. in 2017. Among EU states The Netherlands has been the largest importer from China and Germany the largest exporter to China. Poland imported from China goods summing up to 16322 mln Euro, which accounts for a share of 27,8 \% of Polish import from countries outside the EU. Polish export to China sums up to $2062 \mathrm{mln}$ Euro, which stands for 5\% of the Chinese share in Polish export to countries outside the EU. The majority of goods exchanged between Poland and China consists of machines, other manufactured goods and chemicals (similarly like in the case of goods exchanged between the EU and China - Figure $1)$.

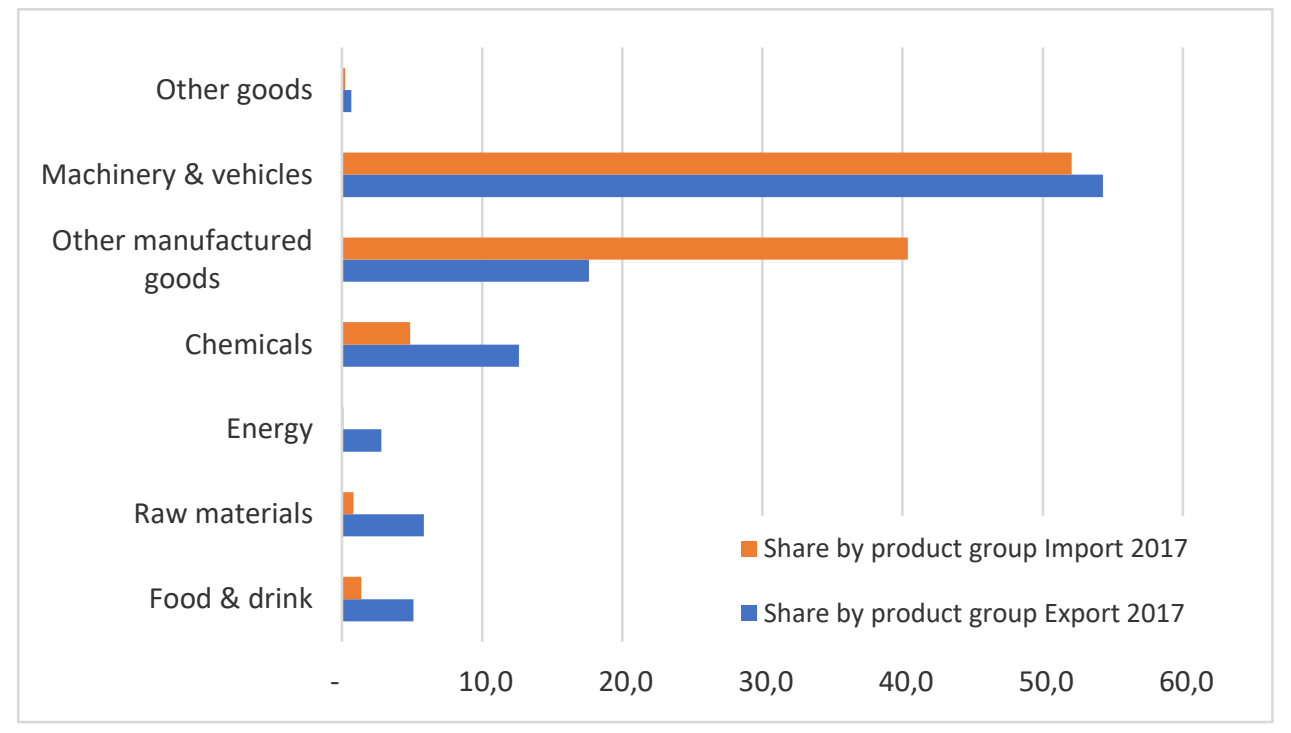

Fig. 1 EU exports to and imports from China by product group 2017 (EUR billion) Source: Eurostat [1]

As China's export to Poland is very small its role on the NSR is more of a transit country to Germany and further to Western Europe. However enhanced by the new transport possibilities offered by the NSR initiative, intensive efforts of Polish exporters to enter the Chinese market and play an active part in the NSR are made. The dynamics of the PolishChinese trade exchange is promising. In 2017 the total turnover of trade exchange between Poland and China increased by $20 \%$ and Polish export to China rose by $18 \%$ [2].

In 2016, 1075000 tonnes of goods were exported from Poland to China by rail and 1421 000 tonnes were imported by rail from China to Poland [3]. The intermodal connections between Poland and China are growing, according to PKP Cargo, the Polish Railway company, they comprise $18 \%$ of all intermodal connections of Poland [4]. Currently, train services on the route China-Poland are performed every day and most of the loads contain industrial machines and bulk. Taking the Chinese demand into account, the export of Polish food, cosmetics, chemicals, paper and wood can be intensified.

Due to its geographical location, Poland can serve as an important hub facilitating distribution of goods in Europe. Since freight on the Eurasian route is mainly transported in containers, container depots, enabling storage of empty containers as well as their repair, maintenance and cleaning, might importantly influence freight traffic in this region. 
In this paper, the criteria for choosing the location of a container depot in Poland is discussed. In this process, the structure of the highway network enabling distribution of containers by trucks to other destinations, as well as green aspects mainly referring to avoiding city congestion caused by trucks transporting containers are taken into consideration.

The remainder of this paper is constructed as follows: first, the role of a container depot in a container transportation chain is underlined and location criteria, introduced in the literature, are presented. Later the infrastructural situation in Poland in the light of the NSR corridor is described and a recommendation of a depot location is formulated.

\section{Depot location problem}

Since the container storage capacity of ports and rail terminals is limited and it is often impossible to extend the storage area due to the neighbourhood constraints, container depots are established in the proximity of the terminals. Container depots can be defined as large facilities located in the vicinity of seaports or rail transhipment terminals embracing different zones in which different activities are performed, e.g. the reparation, cleaning and storage of empty containers [5]. In container depots leased or carrier owned containers are handled, custody of containers between shippers is transferred and storing containers that are currently surplus is performed. Container depots serve as a supply point for empty containers and servicing/repairing containers under contract [6]. Transporting empty containers back to their origin or owner/leasing party is more expensive than keeping them hinterland in a depot where they wait for repositioning. The cost and space required for transportation of a full or empty container are similar but empty containers do not generate profit.

Inland container depots are an essential element of container transportation chains. Location of a depot should be chosen in the proximity of an array of importers and exporters using containers. Importers, after unloading cargo from containers, send them either back to the port/rail terminal, or directly to the exporters (in the frame of the so-called street turns) or they transport them to container depots where they wait for future demand [7]. Inland container depots can also support rail container terminals and ports as storage places reducing congestion at their sites and reducing costs of transportation of empty containers to the rail terminals/ports. A role of a container depot in the container transportation chain is illustrated in Figure 2.

With the predicted rise of intermodal transportation on the NSR, the increase in capacity of container storage space is inevitable. When the inventory capacity limit is outperformed, the stack height is increased, often from standard height of 3-4 containers up to 8 [8]. Such storage areas spoil the landscape and negatively influence the prices of land $[9,10]$. Another important aspect is the increased traffic around container storage places causing an increase of $\mathrm{CO}_{2}$ emissions, noise, congestion and risk of accidents. Therefore the location of a depot should be distant from residential areas.

Truck delivering or pickup of containers at the depots should be well managed in order to avoid congestion and unnecessary waiting times. Time intervals of service should be established and they can be priced differently in order to equally spread the truck arrivals over the planning horizon $[11,12]$.

As storage space is rare and costly and the number of empty containers that need to be stored might accumulate to a substantial amount, decisions are necessary where to locate empty container inventory. This requires high-quality forecasting methods in order to foresee the amount of inbound and outbound empty containers. 


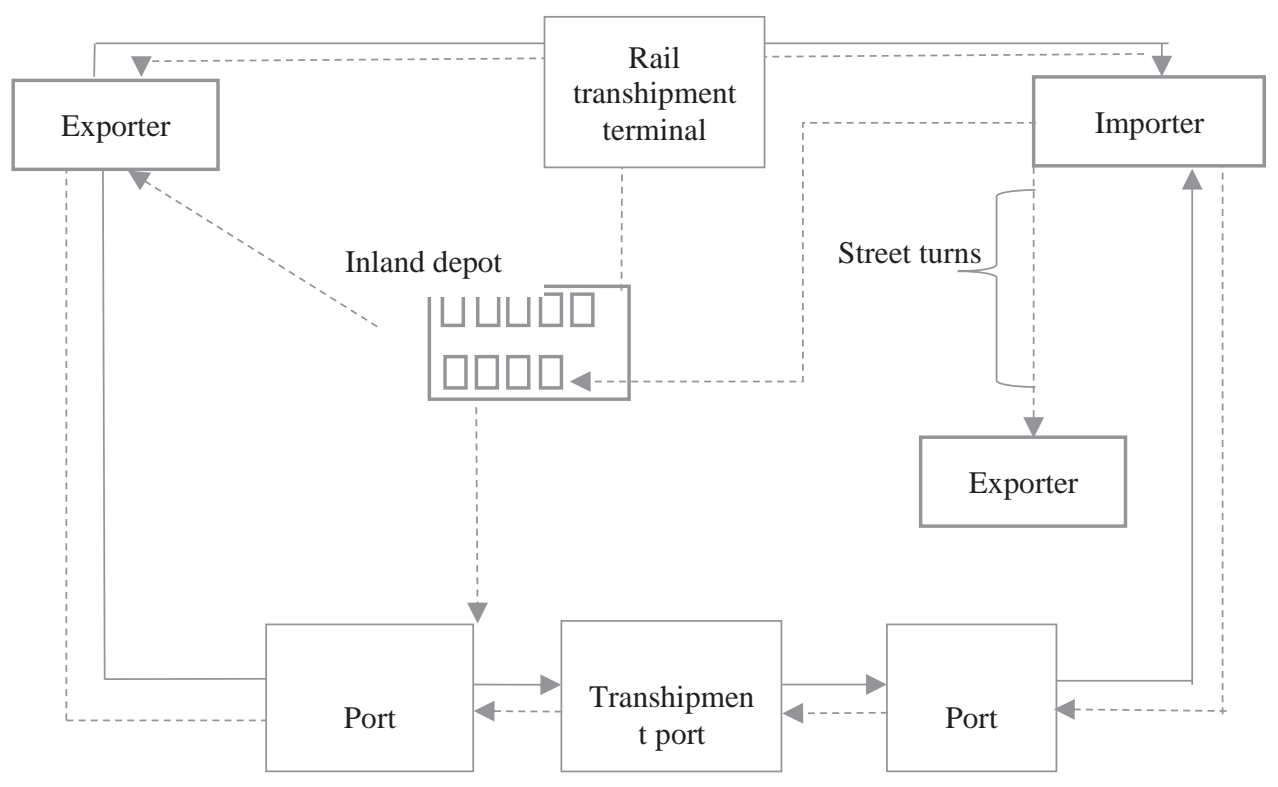

Fig. 2 Container depot role in container transport chain

Insufficient planning of retrieving containers causes reshuffling. It means unnecessary movements of containers which occurs when among any two containers positioned (not necessarily directly) on top of each other the bottom container need to be retrieved earlier [7]. As a consequence, the top container has to be removed before the bottom container becomes accessible. Reshuffling causes cost and energy consumption and should be avoided as much as possible. Methods for optimally stacking and retrieving containers to/from storage yard blocks have been described in Kovalyov et al. [13] and Nossack et al. [14].

The main objective in determining the optimal location of a depot is cost reduction of transporting containers. Palacio et al. [5] propose a multiobjective approach based on the multicommodity capacitated location problem with balancing requirements aiming not only to minimize costs but also to minimize the environmental impact caused by the setting up and maintenance of container depots and by the transport operations inside and in the proximity of the depots. They consider the capacity of the depots as a fuzzy constraint and they use a fuzzy optimization approach to address the problem. They go a step further in their study of 2018 [15] where they design a container depot logistic network minimizing the cost of the whole system, the environmental impact of transport and the environmental impact of establishing and operating of depots with the use of a three-objective, fuzzy optimisation model. They extend the model of Gendron et al. $[16,17]$ by adding two objective functions and considering one more kind of nodes.

Demand and supply of containers are difficult to forecast. Therefore some authors tried to model the location problem in empty container repositioning under uncertainty. Mittal et al. [8] generate scenarios to solve the optimal location of a container depot problem and formulate a two-stage stochastic program with recourse. They address it as a strategic empty container relocation problem as it requires decisions about facility location in the transportation network. They consider the fixed cost of building new depots and transportation cost of repositioning of empty containers. By this means their model solution can recommend the opening of a depot with a higher fixed cost of opening because of the 
benefit of lower transportation costs. Another group of costs included in the model are costs concerning environmental impact.

\section{Infrastructural conditions in Poland}

Container depots in Poland in the frame of the NSR should serve as supporting storage places for container terminals with limited capacity. They should be located in proximity to the container terminals receiving (empty) containers from the EU for freight transport to Asia or closer destinations or receiving loaded containers from China for redistribution within the EU. Depots should be close to importers and exporters using containers and they should be located with good access to the highways to enable convenient distribution of containers. Therefore the access to road and rail transport network should be taken into account. In Figure $3 \mathrm{a}$ and $3 \mathrm{~b}$, both networks are presented with the border crossings indication in case of the rail network presented in Figure $3 b$.

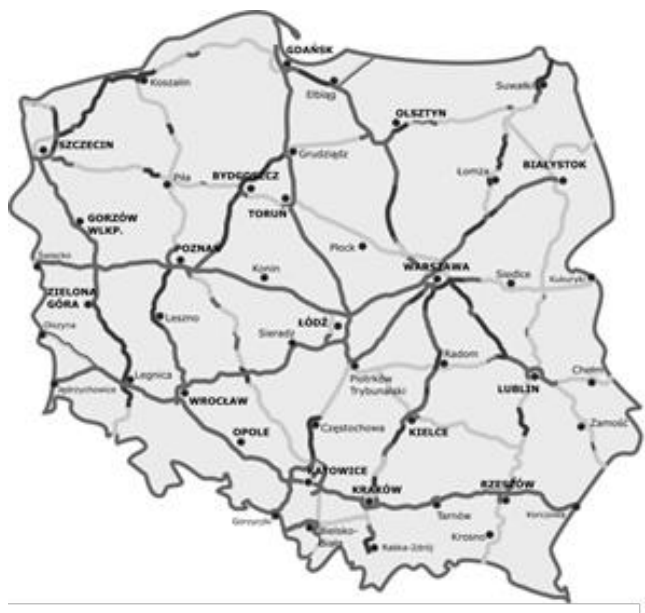

Figure 3a. Roads and highways in Poland Source: A map by Sliwers derivative works of Historia budowy autostrad i dróg ekspresowych.gif, CC BY 3.0 Licence,

File: DocelowyUkladD rog.svg, Wikipedia [18]

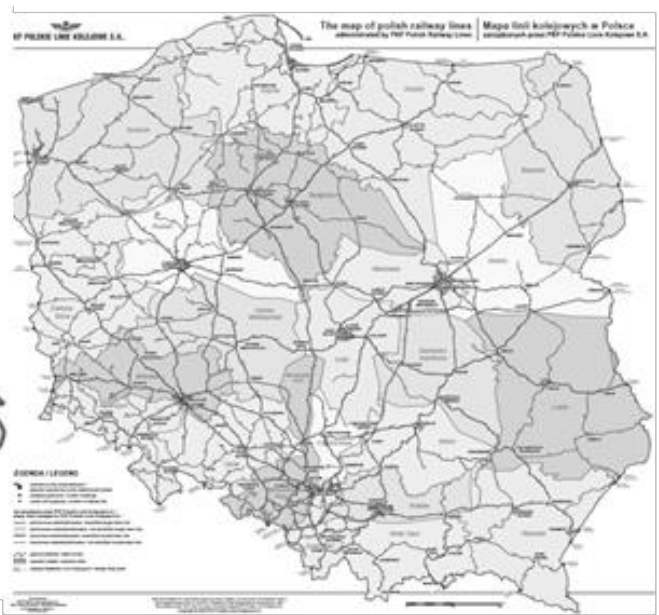

Figure 3b. Railway network in Poland Source: PK P Polskie Linie K olejowe S.A ., www.plk-sa.pl [19]

Both densities of roads and railways are much higher in the Western and SouthernWestern part of the country. Container depots are needed to support the container terminals located on the NSR and link them to highways.

In Poland, inland container terminals have a smaller share in transhipments than sea terminals. Terminals located in the central part of Poland in Warsaw, Pruszkow, Lodz and Kutno have $11 \%$ of share in the annual potential of TEU transhipment in Poland. Another important region is Gorny Slask, where terminals Slawkow, Gliwice, Dabrowa Gornicza have $13 \%$ of the annual transhipment [20]. There is a big discrepancy in a terminal location with the majority located in the central and western part of the country (Figure 4). 


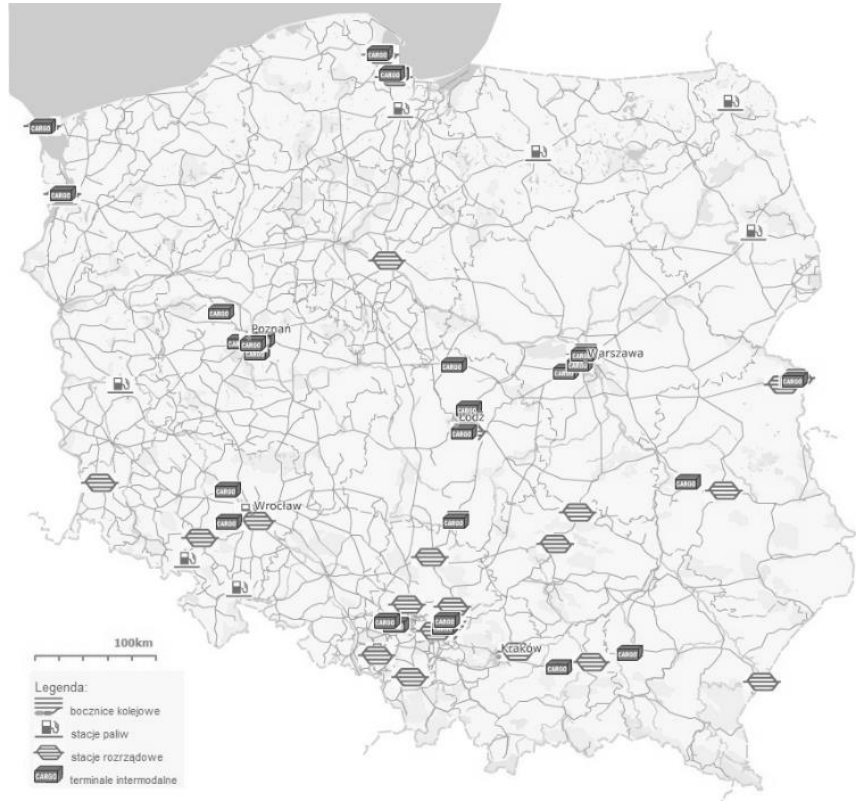

Fig. 4 Container terminals location in Poland

Source: Urząd Transportu Kolejowego; Internet ART s.c. K. Ozimek-Litwin, J. Litwin, M . B aszczak [21]

The terminals with the biggest transhipment potential are Polzug HUB Terminal Poznan, PCC Intermodal - Terminal PCC Kutno, Polzug Terminal Dąbrowa Górnicza, Euroterminal Slawkow and PKP Cargo Centrum Logistyczne Malaszewicze. The last two are crucial border crossings receiving trains with containers from Eastern countries including China.

The main route of the NSR part in Poland leads through Malaszewicze transhipment terminal (at the border crossing with Belarus), which requires a shift from broad to standard track width. The trains to/from China also go through Warsaw and Lodz. Lodz serves as the main logistics hub on the Polish stretch of the NSR, 25\% of trains China-Poland is served there [22]. As a consequence of the political instability in Ukraine, the flow of trains from/to China goes through Belarus, Russia and Kazakhstan. By the shift of train transport from Ukraine to Belarus container terminal Slawkow, which formerly received trains from the East coming through Ukraine, lost its significance on the NSR and Malaszewicze took over this role in this region. Since most of the trains coming from China go through Malaszewicze, the insufficient capacity of this terminal (14 pairs of trains per day [22] cause a capacity bottleneck so that further trains need to wait in Belarus or even Kazachstan. In 2017, Malaszewicze received 2200 trains from China with 40 containers each. Over the last years, it was a significant rise from 17 trains yearly in 2011. According to experts predictions, in 2030 the trains from China will bring to Poland 1 billion TEU, which will be five times more than in 2017. The increase of container transport is supported by the Chinese subsidy to each container reaching 3000-5000 of US \$ [23].

The insufficient capacity of Malaszewicze triggered searching of the Chinese side for other border crossings on the North-Eastern border of Poland. The trials have been performed in Kuznica Bialostocka and Siemianowka. Furthermore, the modernisation works of the tracks on the route Malaszewisze-Warsaw will contribute to congestion and will result in moving some of the trains to the North-East. Therefore the development of intermodal infrastructure including the establishment of a container depot in the North-Eastern region is important to meet the future demand. A depot located near Kuznica Bialostocka 
or Siemionowka terminals at the North-Eastern border crossings and close to the roads to provide convenient transport to local industry (importers and exporters) and further to the North and Central Poland could serve well supporting the container transport in this region. Since in the Northern-Eastern region of Poland many dairy products, machines and mechanical parts producers are located, they seem to have the potential to increase export to China and therefore increase their demand for containers.

Another desired location for a container depot would be a proximity of Lodz as a central hub on the NSR and a place well connected to the industry. There are plans to extend the terminal in the city but it will have a harmful impact on the city in terms of congestion and detrimental emissions. Therefore locating a container depot in some distance from Lodz and good connection to the highways, so that containers can be further distributed by trucks to containers users, is advisable.

\section{Conclusions}

The location of container depots might be a result of competing regions for market share [24] were not the only location but also price decisions, i.e., the incorporation of price competition into competitive location models, has an important relevance. As a result, there might not exist any price equilibria or the multiple local equilibria in prices can be found. Different price sensitivity levels of customers may actually affect optimal locations of depots. Kress and Pesch [25] provide first insights into the performance of heuristic algorithms for these location problems.

\section{Acknowledgements}

This study was supported by Bialystok University of Technology (S/WZ/1/2014).

\section{Reference}

1. Eurostat, China-EU - international trade in goods statistics (2018), A vailable from: http://ec.europa.eu/eurostat/statistics-explained/index.php?title=China-EU_-

international_trade_in_goods_statistics\#M anufactured_goods_dominate_trade_with_ China [A ccessed on $\overline{17} .05 .201 \overline{8}$ ]

2. M. Kalwasinski, Eksport z Polski do Chin najwyższy w historii, Bankier.pl. Available from: https://www.bankier.pl/wiadomosc/Eksport-z-Polski-do-Chin-najwyzszyw-historii-7568470.html [A ccessed on 14.06.2018]

3. Statistics Poland, Transport activity results in 2016 (2017), Available from: http://stat.gov.pl/en/topics/transport-and-communications/transport/transport-activityresults-in-2016,6,12.html. [A ccessed on 16.06.2018]

4. R. K olejowy (2018), A vailable from: http://www.rynek-kolejowy.pl/wiadomosci/nowyjedwabny-szlak-infrastruktura-nie-nadaza-za-przew ozami-87005.html [A ccessed on 17.05.2018]

5. A. Palacio, B. A denso-Díaz, S. Lozano, A fuzzy approach to the location of depots for returned maritime containers, 7th IFAC Conference on Manufacturing Modelling, Management and Control International Federation of Automatic Control, Saint Petersburg, Russia (2013)

6. M. Rahimi, A. A sef-V aziri, R. Harrison, Integrating Inland Ports into the Intermodal Goods M ovement System for Ports of L os A ngeles and L ong B each, Report N 0. 07-01 (2011) 
7. K.A. K uzmicz, E. Pesch, A pproaches to empty container repositioning problems in the context of Eurasian intermodal transportation, Omega - the International Journal of Management Science, in press (2018)

8. N. Mittal, M. Boile, A. Baveja, S. Theofanis, Determining optimal inland-emptycontainer depot locations under stochastic demand, Research in Transportation Economics 42:50-60 (2013)

9. N. Perez-R odriguez, J. H olguin-V eras, The A ccumulation of Empty Containers in U rban A reas: Policy Implications from a Stochastic Formulation, Networks and Spatial Economics 14:379-408 (2014)

10. M. Ramphul, V. Ramesh, V.C. Jaunky, The impact of foldable/collapsible containers on empty container management: a case study at Port Luis, International Journal of Management and Applied Sciences 3:32-39 (2017)

11. K.A. Kuzmicz, E. Pesch, Prerequisites for the modelling of empty container supply chains, Engineering Management in Production and Services 9:28-36 (2017)

12. M. Jarocka, U Ryciuk, Pricing in the railway transport, The 9th International Scientific Conference "Business and Management 2016": Conference Proceedings, Vilnius Gediminas Technical University (2016)

13. M.Y. Kovalyov, E. Pesch, A. Ryzhikov, A note on scheduling container storage operations of two non-passing stacking cranes, Networks 71:271-280 (2018)

14. Y. Nossack, D. B riskorn, E. Pesch, Container dispatching and conflict-free yard crane routing in an automated container terminal, Transportation Science, in press (2018)

15. A. Palacio, B. A denso-Díaz, S. Lozano, A decision making model to design a sustainable container depot logistic network: the case of the port of V al encia, Transport 33:119-130 (2018)

16. B. Gendron, J.Y. Potvin, P. Soriano, A tabu search with slope scaling for the multicommodity capacitated location problem with balancing requirements, Annals of Operations Research 122:193-217 (2003a)

17. B. Gendron, J.Y. Potvin, P. Soriano, A parallel hybrid heuristic for the multicommodity capacitated location problem with balancing requirements, Parallel Computing 29: 591606 (2003b)

18. Wikipedia, Highways and roads in Poland (2018), Available from: https://pl.wikipedia.org/wiki/A utostrady_i_drogi_ekspresowe_w_Polsce, [A ccessed on 04.06.2018]

19. PKP Polskie Linie Kolejowe, A map of Polish railways (2018), A vailable from: https://www.plk-sa.pl/biuro-prasowe/mapy/ [A ccessed on 01.07.2018]

20. M. Jacyna, D. Pyza, R. Jachimowski, Transport Intermodalny - Projektowanie Terminali Przeładunkowych, Wydawnictwo Naukowe PW N, Warszawa (2017)

21. U.T. Kolejowego, Internet A RT S.c. K. Ozimek-Litwin, J. Litwin, M. Baszczak, A map of intermodal terminals in Poland (2014), Available from: https://utk.gov.pl/pl/aktual nosci/4164,M apa-obiektow-infrastruktury-uslugowej-ibocznic-kolejowych.html [A ccessed on 01.07.2018]

22. J. Jakobowski, K. Poplawski, M. Kaczmarski, The Silk Rail Road The EU-China rail connections: background, actors, interests, Centre for Eastern Studies, OSW Studies 72 (2018), A vailable from: https://www.osw.waw.pl/sites/default/files/studies_72_silkrailroad_net.pdf [A ccessed on 09.06.2018]

23. Rzeczpospolita, Wojna o obsługę Chińczyków [Fighting for servicing the Chinese] 114:11054 18 M ai, A 24 (2018)

24. D. K ress, E. Pesch, (r|p)-centroid problems on networks with vertex and edge demand, Computers and Operations Research 39:2954-2967 (2012)

25. D. K ress, E. Pesch, Competitive location and pricing on networks with random utilities, Networks and Spatial Economics 16:837-863 (2016) 